\title{
Engaging Economics and Traffic Engineering Students in Community Issues Using the MultiCreation Approach
}

\author{
Renata Petrevska Nechkoska \\ University St. Kliment Ohridski, Faculty of Economics, North Macedonia \\ and Ghent University Belgium, Faculty of Economics and Business \\ Administration, Belgium \\ renata.petrevskanechkoska@ugent.be
}

\section{Daniela Koltovska Nechovska}

University St. Kliment Ohridski, Faculty of Technical Sciences, North Macedonia

daniela.koltovska@uklo.edu.mk

\author{
Marjan Angeleski \\ University St. Kliment, Faculty of Economics, North Macedonia \\ marjan.angeleski@uklo.edu.mk
}

\begin{abstract}
Effective teaching methods for the coming generations of pragmatic students and teachers are evolving towards much greater involvement on all sides, attempting to bridge real life and academia in innova-tive ways. Our theoretical foundation lays upon the Triple Helix, n-Tuple Helix theory and the innova-tion triangle, but in a problem-based multidisciplinary setting. After introducing and validating the Mul-tiCreation approach in teaching/learning for the business-academia collaboration, where multiple disci-plines, diverse profiles of students, professors, and managers have taken up various roles to address relevant business issues, we were encouraged to expand its applicability beyond the business world - toward societal problems. We retained the problem-based and participatory learning but shifted the positioning of the problem towards the safety of primary school children, incorporating economic, pro-ject-based, managerial, traffic engineering, logistical, regulatory, and governance issues. By including two primary schools, collaborating with their principals, advisory teams, and teachers, as well as chil-dren and parents, in two different cities, we aimed to provide complete research, engineering and educa-tion for the stakeholders so that the schools could just hand in documentation to the relevant municipal bodies to be acted upon effectuation. The involved students came from two faculties of economics and traffic engineering, steered by three university professors on the subjects of project management and basic and advanced techniques for traffic management. The blended learning components took place as prescribed in the MultiCreation approach, during two semesters of two academic years. They combined countermeasures and solutions. The
\end{abstract}

ORIGINAL SCIENTIFIC PAPER

RECEIVED: JUNE 2021

REVISED: AUGUST 2021

ACCEPTED: SEPTEMBER 2021

DOI: 10.2478/ngoe-2021-0015

UDK: $378.147: 656.1$

JEL: A12, D78, 035 R41

Citation: Petrevska Nechkoska, R., Koltovska Nechovska, D., \& Angeleski, M. (2021). Engaging Economics and Traffic Engineering Students in Community Issues Using the Mul-tiCreation Approach. Naše gospodarstvo/Our Economy, 67(3), 2937. DOI: 10.2478/ngoe-2021-0015.

\section{NG OE}

NAŠE GOSPODARSTVO OUR ECONOMY

\begin{tabular}{c|c|c|} 
Vol. 67 & No. 3 & 2021 \\
\hline pp. $29-37$
\end{tabular}


MultiCreation approach has been enhanced regarding its components and workflow and its effectiveness has been validated in a multi-stakeholder environ-ment of direct and indirect educational beneficiaries.

Keywords: Problem-based learning, participatory learning, MultiCreation approach, Traffic Engineering, communityacademia collaboration

\section{Motivation and Theoretical Background}

Establishing functional bridges among disciplines, industries, countries, students, domains, subjects, applications, and diverse stakeholders is an ongoing process - and the goal to facili-tate university students to apply their learnings in a guided manner has been our motivation to take up an approach already applied in practice that helps achieve these goals - the MultiCrea-tion approach by (Petrevska Nechkoska and Angeloska Dichovska, 2020). We retained the problem-based and participatory learning, situated learning (Lave and Wenger, 1991, 1996), but shifted the positioning of the problem towards traffic safety of children in primary schools - incorporating economical, projectbased, managerial, traffic engineering, logistical, regulato-ry and governance issues.

In any problem-driven research, one of the main theoretical challenges is positioning the mul-tidisciplinary setting of the scientific domains, which are interrelated, so as to address real problems in a conceptual manner. Hence, using our theoretical backgrounds we touched upon management, governance, engineering, traffic, innovation, higher education - hoping to achieve at least an initial brief portrayal of the incorporated disciplines.

In its broadest sense, there are constructivist efforts to create ecosystems, communities of practice, networks (Ataizi, 2012) which have the levers of 1 ) filtering - organising and manag-ing important information, 2) amplifying - helping to understand important but little known information, 3) investing and providing - offering means to provide members the resources they need, 4) convening - bringing together different individuals and groups, 5) community building promoting and sustaining values and standards and 6) learning and facilitation - helping work more efficiently and effectively, all in continuous iterative cycles (JRC, 2021). Universities ought to respond to societal needs (Farnell, 2020) and numerous such endeavours in fact are underway though more are necessary - university-led and stakeholderled initia-tives, connecting engagement to 'accountability', 'relevance' and 'impact'. Furthermore, by linking public engagement and research impact, the authors conclude that public engagement is a pathway to impact. Phillips et al., 2015, recognise that corporate social responsibility initiatives extend beyond meeting the immediate interests of stakeholders, and they stipulate and profile diverse roles such as: 1 . The role of the entrepreneur: social mission and opportunity recognition; 2. Networks and systems; 3. The formation and development of cross-sectoral partnerships; and 4. The role of institutions. Each of these roles are to be populated by various actors, dynamically, even interchangeably. Traditionally, such initiatives and projects, under the initial offerings of services, platforms, hubs, the purpose ultimately aimed for requires much profiling and indepth work necessary for a impelling shared vision, participation, and engagement, community and knowledge, trust and confidence and communication (Li, 2005) (Booth, 2012). From an entrepreneurial perspective (O'Shea et al., 2021) have identified the stages of Co-intuiting, Cointerpreting, Co-integrating, Shared sustainability intention and Emotional climate, with three levels of details, depending on the context of application, and they are valid in a diverse set of entrepreneurial activities, including, but not limited to, social entrepreneurship. The theories found most in practice pave the foundation to ignite the trans-formative capacity of all forms of collaboration (e.g., the $6 \mathbf{i}+$ model, strategy, and approach: international, interdisciplinary, intersectoral, intergenerational, innovative, inclusive...) to al-low interactions to emerge around purposes for the common good (Caro, 2019; Caro et al., 2020). The active engagement of stakeholders from the n-helix spectrum is considered a must (Caro \& Serra, 2020). The n-tuple helix theory (Leydesdorff, 2012), gradually developed via the Triple Helix, Quintuple Helix theory) (Etzkowitz, 2008; Etzkowitz and Leydesdorff, 1995, 1998, 2000) relates the universities, industry and government configuration with posi-tive, negative overlaps among the subsystems, all having diverse levels of subdynamics of national or regional scope. Our main inspiration resides in such a setting, while the innovation triangle and engine which produces effects is the workflow in such systems.

On the theoretical background of our content of interest traffic engineering - we are touch-ing upon contextual factors and a multi-stakeholder perspective. Traffic accidents have been harming enormous numbers of people for over a century. For traffic safety policy to be suc-cessful, it must have only one goal - protecting the public and community. The public and community must recognize and support this goal (Evans, 2004). This statement sounds very promising, but when it comes to reality, it appears to be very difficult to achieve (at least ac-cording to the experience in defining policy instruments, project management, and managing traffic safety targets in the Republic of North Macedonia). As the traffic demand increases in and around public schools, concerns regarding traffic safety have been raised. To respond to these concerns, traditionally a law enforcement approach has been taken.

But is the law and police enforcement the most effective way to approach traffic safety issues? After creating and validating the MultiCreation approach in academic teaching/learning, the main idea of this paper was to expand its applicability beyond the business world into societal problems in a way that will encourage and inspire individuals to look for new approaches and to be creative in designing 
appropriate traffic safety solutions (Petrevska Nechkoska and An-geloska Dichovska, 2020), (UKLO for the Community project ${ }^{1}$ ). Best practices show that a consistent, integrated, and comprehensive approach is needed. Implementation of multidisci-plinary "4-E approach" (Education + Enforcement + Engineering + Environment) (Fromkin et al., 2004) became 'conditio sine qua non' to achieve a sustainable and safe transport system, taking care of human lives and the quality of living aiming towards liveability in our neigh-bourhoods and integrated traffic planning.

After analysing the "State-of-the-art", or "Global Best practices" that have successfully demonstrated 4-E implementation in road safety-related projects in many different countries, we were motivated to make a diversion from the traditional approach to a new 4-E approach, in designing potential solutions regarding children's traffic safety in school zones. An appro-priate set of problemoriented solutions, founded on real data collection for different transport system users, and project documentation and a project management outline as content are pre-sented.

These activities have enabled collaboration, network, creativity, knowledge, skills, and compe-tences (CEDEFOP, 2019) for all stakeholders, achieving a synergistic effect in addressing (and hopefully solving) rather complex societal issues.

This paper will showcase (and basically follow the same presentation construction) the under-lying methodology we used to enhance the chosen MultiCreation approach for addressing societal issues (ADDIE) and help foster the Action Design Research on project and content generation and collaboration. We also portray the MultiCreation approach for addressing soci-etal issues via its components and roadmap, portraying how it aligns but also how it differen-tiates from that used for business issues. Conclusions and prospects end the paper.

\section{Methodology}

We have taken the MultiCreation approach as a baseline designed for addressing business problems via broad, multidisciplinary, multi-stakeholder collaboration (Petrevska Nechkoska and Angeloska Dichovska, 2020) and applied it to another kind of problem - a societal issue - by involving numerous and diverse stakeholders, two different faculties and three subjects, as well as stakeholders from two towns distinctive from the basic MultiCreation approach. The instructional design (David Merrill et al., 1996; Wagner, 2011) and didactics (Tubbs, 2014) that guided us have been used to engage and teach students through problem-based learning by doing, while producing effects for the entire community. The ADDIE model (Kurt, 2017) has been followed to incorporate analysis, design, development, implementation, evaluation in the formative and summative senses, complemented by the dual mission of the Action Design Research - ADR (Sein et al., 2011) in the information systems domain. The project was man-aged using the DENICA method for tactical management in complexity (Petrevska Nechkos-ka, 2019). This paper follows the same structure as the first on MultiCreation.

Here are the ADDIE model components that will enable comprehension of the roadmap we took and how the analysis and findings have been generated.

\section{Analysis - A}

The analysis stage in this instance was conducted in collaboration with the schools, the facul-ties, subjects, and among the participating professors. The positioning of the problem was as follows: The societal problem of traffic safety in the proximity of primary schools for primary school children, in two primary schools from two towns, collaborating with their principals, advisory teams and teachers, as well as children and parents. The students came from two faculties - Faculty of economics in Prilep and Faculty of traffic engineering in Bitola, both at the University St. Kliment Ohridski, Bitola, North Macedonia. The implementation was steered by three university professors on the subjects of project management and basic and advanced techniques for traffic management, out of which one acted as project manager to facilitate the entire project, while the two advised in their subjects, adaptation of instruction and outcomes, as well as the multidisciplinary threads beyond the typical subject matter. The blended learning components took place as prescribed in the MultiCreation approach, during two semesters of two academic years (summer semester of 2019 and winter semester of 2020). The title of the project was: "UKLO for the community" ("УКЛО за заедницата”) - acronym for the University St. Kliment Ohridski - UKLO to denote contribution to the com-munity in both towns.

This instance of the MultiCreation approach in societal issues enlisted stakeholders from the two faculties from the two towns: $50+$ undergraduate students, 3 professors, 50+ primary school staff (administrative and teaching), 50+ parents, 300+ school children, 10+ collabora-tors (police, municipality advisors, other stakeholders, ...), 2 social entrepreneurship advisors, and an alumni network that supported the final event (Western Balkans Alumni Association $^{2}$ ).

The main goal of the project was to provide complete research, engineering, and education for the stakeholders so that the schools could just hand in necessary documentation to the rele-vant municipal bodies to be acted upon effectuation.

\section{Objectives for the students:}

- To enable theoretical and practical knowledge of the concepts in the separate subjects: pro-ject management and basic and advanced techniques for traffic management as well as mul-tidisciplinary crossfertilization; 
- To facilitate application of acquired knowledge in a societal domain;

- To facilitate the students towards analysis and evaluation of a problem - and deconstruct it using the project management concepts and mechanisms, using a broad stakeholder perspec-tive;

- $\quad$ To improve the skills of: problem solving, learning by doing, cross-fertilisation, social entre-preneurship, teamwork, situation awareness, time management, creativity, innovativeness, adaptability, initiating change, professional communication

- To enable proficiency in virtual teams' collaboration along with all necessary tools and tech-niques

- $\quad$ To enable feeling of belonging and pride for contributing to society beyond regular student life

- To 'equip' the students with a proactive roadmap on social entrepreneurship and project management

- Motivate social entrepreneurship and voluntary contribution to society by the involved pro-fessors

\section{Objectives for the higher-education institutions (university):}

The ones apprehended by the MultiCreation approach are as follows:

- Establish subject to subject and teacher to teacher collaboration in a multidisciplinary man-ner;

- Trace a multi-stakeholder collaboration focused on a problem, utilizing various resources in a broad and complex ecosystem;

- Complement lectures with practical use and applicability;

- Referential reputation as competent centre for scientifically sound business advice to in-crease partner network and future revenues;

- Promote use of the e-learning platform and portals per subject, per project, per study group;

- Streamline the focus of different subjects towards mutual compatibility - perceivable also by the students" (Petrevska Nechkoska and Angeloska Dichovska, 2020).

Accompanied by the following two objectives:

Bridge two faculties within a university, addressing the same problem from different per-spectives as one entity of diverse collaborators;

Build a reputation for the university as a contributor to the society with tangible projects.

\section{Objectives for the schools:}

- $\quad$ Engage actively in solving problems without waiting for central municipal or state-directed action that requires funding and priorities;

- Practice integral curriculum (as prescribed by the Ministry of Education);

- Open space for collaboration with universities, parents, neighborhoods, institutions, citizens on problem-based approach (aside from political and hierarchical context).

\section{Design - D}

In applying the MultiCreation approach for societal issues, we adhered to the principles of 'practice-inspired research and theory-ingrained artefacts, reciprocal shaping of the participant and their context, and mutually influential roles of the multi-participant landscape' (Sein et.al. 2011) (Petrevska Nechkoska and Angeloska Dichovska, 2020). Blended learning (Petrevska Nechkoska and Mojsovska Salamovska, 2017) again assists the multimodal collaboration channels, which is especially necessary since the geographic and physical distance has been substantial having participants from at least two towns and their regions. The E-platforms and traditional channels have been present and utilised:

(1) Moodle as an E-learning platform mainly used for placement of materials and asynchro-nous, usually one directional teacher-students communication; as well as bidirectionally through student assignments, forums and other activities. The project portal contained all in-structions and timeline of developments so that every participant (students, managers, teach-ers) could always orient, revert, check and project own and team actions.

(2) Facebook groups have been used for rapid communication where confirmative response was expected.

(3) Storage space in the cloud, USB sticks.

(4) Polls, surveys, collaborative writing, and asynchronous remote project work by using the Google Sheets, Forms, Docs, and similar tools.

(5) Skype/Viber served as a synchronous remote team communication.

(6) Free mobile apps/messengers for instant messaging used for urgent matters.

(7) E-mail correspondence.

(8) Teaching and contact hours, as well as consultations person-to-person, and group/team consultation on-campus (Petrevska Nechkoska and Angeloska Dichovska, 2020).

\section{Development - D}

Complementary to the alignment of the instruction for the subjects, the project entailed actual project management on the core team of stakeholders from all institutions (including students, parents, relatives, neighbours and school children) to be able to go through the respective stages and achieve the expected outcomes.

These are the activities that took place (most important ones):

- Negotiations with the primary schools regarding what the problems are and how we could help;

- Cooperation agreement/memorandums between the faculties and the schools;

- Appointment of persons in charge of communication with each stakeholder;

- Enlisting students willing to participate in the project from both faculties;

- $\quad$ E-learning (Moodle) platform portal for the project;

- Comprehensive onboarding and situational project document, disseminated to all stakehold-ers with 
necessary guidelines on the project, expectations, governing principles and commu-nication rules;

- Meeting of the three professors as the core team (frequent);

- Kick-off event including media dissemination;

- Tracing the stages for group work;

- Alignment of the subject class content (lectures and exercises) with the project.

- Drafting specific responsibilities as up to 10 'musthaves' from each student participant per subject (to be evaluated and graded properly and in relation with the other non-participating students);

- Outlining generic responsibilities for the students (from managerial aspect, professional communication, winwin mindset...);

- Timeline of activities and keeping alert for modifications;

- Setting up teams of students from each subject from each faculty as a means of merger be-tween the faculties (teams are consisted of members of both faculties);

- $\quad$ Surveying, interviewing the stakeholders - to report on progress and to engage further on

- Inspiring school teachers to incorporate the issues in their daily lectures;

- Final event with all participants;

- Ongoing PR activities on multiple channels;

- Certificates, confirmations for internships and other administrative and logistical issues.

These components are taken from the MultiCreation approach for business-academia collabo-ration, while being enhanced and extended for societal issues applicability.

\section{Implementation - I}

The project from idea to realization lasted for a year, spread over two academic semesters. The core team of three professors had meetings on a regular basis (at least once per week) and the project manager coordinated the stakeholder collaboration, dissemination, logistics, authoriza-tions, and all other aspects to make the project possible. Consultations with the students were held on the level of subject, but also as teams collectively. All instruction materials and guidelines were placed on the e-learning portal Moodle ${ }^{3}$, as one stop shop for dissemination and collaboration, as were reports, data, repositories, measurements, etc. Use of best practices in similar situations was facilitated, as well as conceptual and implementational activities in the schools, which also met and aligned accordingly between one another. Parents and neighbors were surveyed, interviewed, participated in focus-groups; measurements and traffic data were obtained on the two locations one semester. Student mentors from the previous semester were engaged. The creativity was at its best - all stakeholders produced a remarkable set of videos, scenarios, tools, promotional materials, workflows, games, lecturing content, to address the problem in a collaborative manner.
A specific note from the Faculty of traffic engineering is as follows:

"Prior to the development of solutions, a thorough understanding of the issues of all included participants was necessary. For that purpose, an extensive review of the current road network design around school areas has been investigated, the traffic flow data for vehicles, pedestri-ans, and bicycles have been obtained by manual count method. Additionally, input from prin-cipals of each school, discussions from parents' council members have been analysed. The so-lutions were categorized into two groups:

(i) solutions that can be applied consistently to every site

(ii) those that applied to the specific school; both include a successful mix of different traffic engineering measures such as:

- Traffic engineering elements and pedestrians' treatments design,

- Traffic engineering elements and bicycle treatments design,

- Traffic calming measures design,

- "Kiss \& Ride System” design for a school zone.”

These measures were designed and evaluated in the microsimulation environment by using the VISSIM microsimulator for the selected primary schools. Proposed solutions provide re-duced conflict points between vehicles and vulnerable users, decreased traffic congestion, travel time, and delay, protection of the environment.

Specific note from the Faculty of economics is as follows: "Since the project management processes belong to five major project management process groups (Initiating; Planning; Executing; Monitoring and Controlling and Closing), the main goal of the EFP team members was to perform some of the initiation and planning project management process groups i.e. to prepare management issues of the project documentation and to perform project plan description. Namely, EFP team members were in charge to:

- describe the problem needs and problem justification

- define goals and objectives of the project

- define target groups;

- develop project activity plan with duration of the project;

- define expected outcomes;

- define relevant milestones and deliverables;

- define known risks and how they will be overcome;

- develop a project budget etc.”

\section{Evaluation - E}

Following are our insights into the formative and summative evaluation that were used to pro-vide learning outcomes, surveying recent progress, and clarifying prospects for 
further ad-vance, throughout the project and around the achieved outcome.

Formative evaluation denoted daily communication and reflection, within the scope of the project. The students have an opportunity to reflect on and demonstrate their thinking, accu-mulated knowledge regarding project objectives and goals. The communication channels were open literally at all times for discussion and reflection regarding student questions. Addition-ally, the teachers communicated with a wide spectrum of stakeholders, such as policymakers and nonprofit organizations.

Summative Evaluation analysed of student's learning outcomes and learning objective in the project. The students were asked to fill in a 25-question questionnaire in different formats to be able to assess and give feedback regarding their experience with the project. All 22 stu-dents that reached the final stage filled in the questionnaire with statements of exceptional experiences and insights. When analysing the feedback, the researchers identified existing benefits and future potentials.

The improvement of knowledge to cope with real problems, the application of new technolo-gies for communication such as Moodle, implementation of sophisticated software tools for analysis and evaluation of different solutions, a synergy through incorporating a range of spe-cialised knowledge between different students' profiles are just some of the answers to which over $80 \%$ of students answered positively. Regarding the most prevalent problems we can emphasize: difficulties in mutual communication and coordination, teamwork, troubleshoot-ing, and interpersonal relationships; some occurrences of lack of materials and time, as well as insufficient knowledge in the IT domain.

As nine key benefits that the students stressed are the following (ranked highest according to the number of statements):

1. Development of self-worth,

2. Self-confidence,

3. Critical thinking,

4. Teamwork,

5. Communication skills,

6. Friendships and networking,

7. Practice and experience,

8. New knowledge (societal entrepreneurship, virtual team collaboration, economical and managerial aspects for technical sciences students and vice versa - technical sciences for stu-dents of economics),

9. Satisfaction, motivation, and increased ambition.

\section{Summative Evaluation: Analysis of multiple stakeholder's opinions and advice}

The school principals, teachers, decision-makers, and representatives were present at the final event, where the teams presented, elaborated on, and clarified their work, analyses, and inno-vative solutions, and ceremonially handed this as project reports to the school principles. The feedback was remarkable, with ambitions for real implementation and fast reaction of munici-pality policymakers to realize the projects. Policymakers must understand the conceptual aspects of the projects to provide wider community benefits.

\section{The MultiCreation Approach for Societal Issues Components and Roadmap}

Considering the "MultiCreation" approach established by Petrevska Nechkoska and Ange-lovska Dichoska (2020), we have developed a new model for collaboration among different stakeholders (in this case: academia, policy makers, community, and non-profit organizations) aiming to address community problems and facilitating value with co-creation. The model is generic, participatory, iterative, consisted of three different interconnected phases with con-nected processes in each (Figure 1). On this occasion, we are describing the main phases and stages of a mechanism that functions like a funnel, having feedback and connection loops among all stages during the project.

\section{Phase 1: Problem identification}

In the first phase, stakeholders, primarily community members and non-profit organizations (in our case the model has been tested with primary schools as non-profit organization repre-sentatives), take into deliberation a plethora of identified problems. In accordance with welldefined criteria, they evaluate the priority of every element for further consideration.

\section{Phase 2: Solutions identification}

Once a priority problem has been identified, the means of overcoming the problem should be generated. Therefore, the second phase begins with brainstorming to generating ideas to this end, including representatives of all stakeholders' groups. Later in this phase, representatives from academia and policy makers perform in-depth analysis and define appraisal criteria in order to select a feasible solution. Appraisal criteria can be either quantitative or qualitative, but they should take into consideration at least technical, economic, financial, managerial, legal, and environmental issues regarding the proposals. The key deliverables from the second phase are project documentation and a comprehensive description of the solution(s) that can be implemented.

\section{Phase 3: Problem solving and solution implementation}

The third phase is the implementation process of the project proposal and should lead towards stakeholder satisfaction. Stakeholders work together to implement the project. Collaboration and communication among stakeholders is a crucial part of the project implementation. There-fore, those processes require feedback, not only by the community but from policy makers, academia, and non-profit organizations 
as well. Finally, since the model is iterative, the improvement of the implemented solution can be done across the phases and stages of the mod-el. Furthermore, beside adjustment of the implemented project through iterations, a new prob-lem can be addressed, and a new solution can be generated and implemented.
Stage 5: Investigating existing knowledge, establishing a foundation for the generation and creation of new innovative solutions and contributions

Phase 3: Problem solving and solution implementation Stage 6: Guiding students to apply what they

Figure 1. The generic iterative model for collaboration among academia, policy makers, community and non-profit organizations addressing societal issues

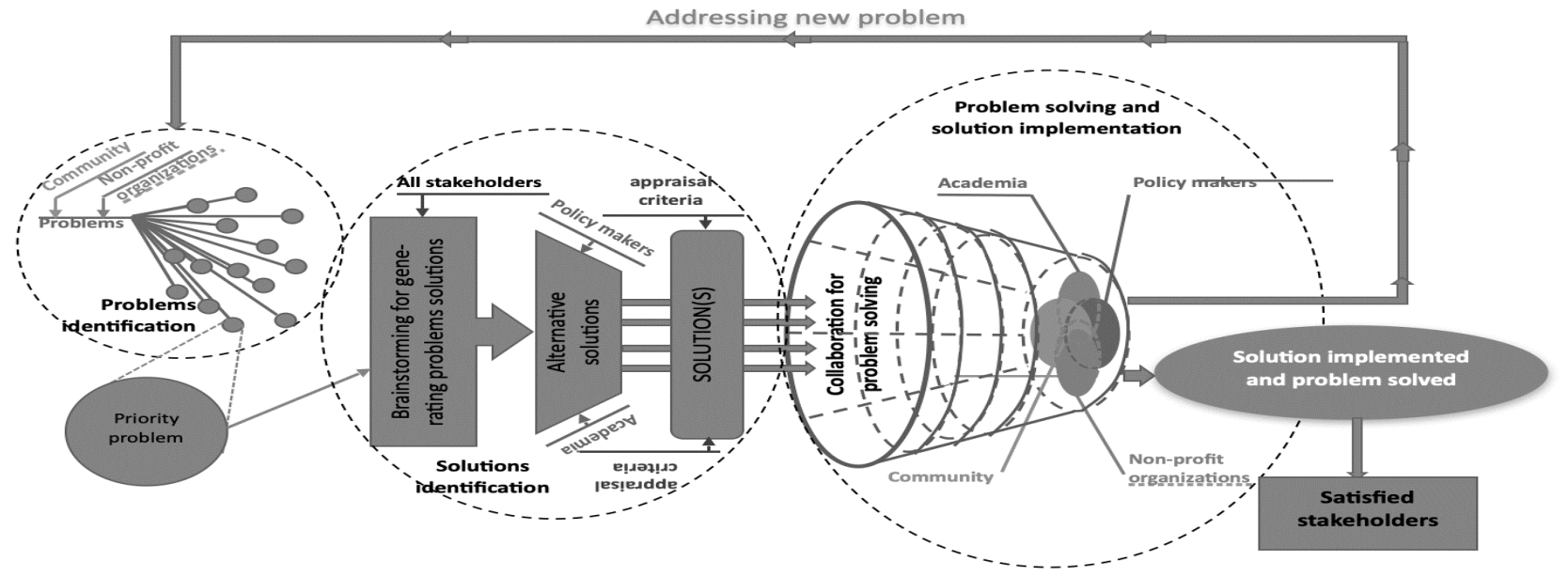

Source: Authors

The MultiCreation model for addressing societal issues adheres to the main principles of the approach, but the difference it introduces is bundling the stages in phases since the stakehold-er ecosystem is much broader in cases of societal issues, and the complexity increases.

Here are the regular stages as outlined in the initial MultiCreation approach (Petrevska Nechkoska, Angeloska Dichovska, 2019) and how they align within the MultiCreation for societal issues phases.

Phase 1: Problem identification

Stage 0: Identifying the problem in the real environment and finding institutional, civil society, public, media ... partner(s) to collaborate

Stage 1: Examining the study programs to find at least 2 subjects that can address the problems through the curriculum

Stage 2: Responsible team of professors address the knowledge base in the respective domains and search for possible solutions. This step encompasses also the current scien-tific domains of the chosen subjects

Stage 3: Informing the business partner about the research and technology that will be used to address their problem, examining their aspects of research \& technology

Phase 2: Solutions identification

Stage 4: Organizing the main components within the HEIs: lectures, lab exercises, stu-dents, teams, timeline, documents, consultation, communication learned in the subjects with what they investigated as possible solutions towards applying and/or creating new knowledge

Stage 7: Facilitating teamwork on all sides, clearing up ongoing problems, maintaining communication channels, receiving feedback (formative and summative)

Stage 8: Checkpoints with the societal partners briefings, fine-tuning, resolving issues ... and finalizing the project with presentations of the reports and solutions to the ini-tially defined problems, receiving feedback (formative and summative)

Stage 9: Instigating curiosity and creativity on the partner side for application and evaluation of the novel solutions to existing problems offered by the stu-dents/professors

Stage 10: Contributing to the instructional design theory and practice, as well as the re-spective disciplines of the investigated problem, and the disciplines of the subjects that took part in the project, dissemination, multiplication, instantiation

\section{Conclusions and Future Prospects}

Our endeavour to engage university students and teachers to address societal issues and learn significant subjects such as project management and basic and advanced techniques in traffic management along the way by collaborating in engaged setting has resulted in knowledge and value co- 
creation for all involved stakeholders. The MultiCreation approach was an appropri-ate foundation that traced the steps - pointing out the roadmap and components needed, while the team of professors guided the entire project in specific content- and context-related realisation. We have been able to experience problems of applicability and point out specifics of addressing societal issues vs business problems, as well as a very broad range of stakehold-ers, geographic dispersion, two faculty profiles of students and non-business and non-profit voluntary motivation. On the positive side, the goal to help the societies we live in by invest-ing nonmonetary values such as competence, time, professionalism, and devotion by the en-gaged professors, has resulted with motivation and respect by all direct and indirect beneficiaries who were encouraged and acted in creative and innovative ways, not practiced before the project. On the negative side, in spite of the great effort and intellectual output, creating complete documentation for the schools that would otherwise have been managed by the no-toriously slow central municipalities, has still not led to a rapid implementation. Ultimately, we believe (as authors, researchers, scientists, professors, volunteers) that the project resulted in improvements for the students and all other stakeholders on many levels, even if the tangi-ble results have yet to be seen.

\section{Endnotes}

${ }^{1}$ UKLO for the Community Project, Ekvilibrium magazine, Faculty of Economics Prilep, No.28, June 2019, http://eccfp.edu.mk/files/biltens/ekvilibrium28.pdf

2 Western Balkans Alumni Association, https://www.westernbalkans-alumni.eu

${ }^{3}$ http://moodle.eccfp.edu.mk/course/view.php?id=190

\section{Acknowledgement}

This academia-business and academia-societal collaboration has been supported by the Western Balkans Alumni Association https://www.western-balkans-alumni.eu/about-wbaa/ and https://ec.europa.eu/education/node_en

\section{References}

Ataizi, M. (2012). 'Communities of practice', in Seel, N. M. (ed.), Encyclopedia of the Sciences of Learning, Springer US, Boston, MA.

Booth, S. E., (2012). Cultivating knowledge sharing and trust in online communities for educators. Journal of Educational Computing Research, 47(1), 1-31.

Caro-Gonzalez, A. (2019). The "6I Research Model”: Evolution of an Innovative Institutional STI Policy Framework at the University of Deusto. Journal for Research and Technology Policy Evaluation, 48, 104-112. DOI: 10.22163/fteval.2019.376.

Caro-Gonzalez, A., \& Serra, A. (Coords.) et al. (2020). Towards social innovation ecosystems: From linear pairwise forms of interaction to common-purpose-driven networks for shared prosperity. Position Paper, Bilbao.

Caro-Gonzalez, A., \& Ferreira-Lopes, L (2020). Universities in transition: The 6i Model for strategic governance and management. Economic and Social Changes: Facts, Trends, Forecast, 13(1). DOI: 10.15838/esc.2020.1.67.13

CEDEFOP. (2019). Overview of national qualifications framework developments in Europe. Retrieved from https://www.cedefop.europa.eu/files/8609_en.pdf

David Merrill, M., Drake, L., Lacy, J . M., Pratt, J., \& the ID2 Research Group. (1996). Reclaiming instructional design. Educational Technology, 36(5), 5-7.

Etzkowitz, H. (2008). The Triple Helix: university-industry-government innovation in action. London: Routledge.

Etzkowitz, H., \& Leydesdorff, L. (1995). The Triple Helix-university-industry-government relations: a laboratory for knowledge-based economic development. EASST Review, 14, 14-19.

Etzkowitz, H., \& Leydesdorff, L. (1998). The endless transition: a "Triple Helix" of university-industry-government relations, introduction to a theme issue. Minerva, 36, 203-208.

Etzkowitz, H., \& Leydesdorff, L. (2000). The dynamics of innovation: from national systems and 'mode 2' to a Triple Helix of university-industry-government relations. Res Policy, 29(2), 109-123.

Evans, L. (2004). Traffic Safety. Bloomfield Hills, MI, Science Serving Society, pp. 412-425.

Fromkin, H., Geller, R. J., \& Rubin, L., (2006). Safe and Healthy School Environment. Oxford University Press.

Farnell, T. (2020). 'Community engagement in higher education: trends, practices and policies', NESET report, Luxembourg: Publications Office of the European Union. DOI: 10.2766/071482.

JRC (2021). The Communities of Practice Playbook - A playbook to collectively run and develop communities of practice.

Lave, J. and Wenger, E. (1991). Situated Learning: Legitimate peripheral participation. United Kingdom: Cambridge University Press.

Lave, J., \& Wenger, E. (1996). Situated Learning: Legitimate peripheral participation, learning in doing. United Kingdom: Cambridge University Press.

Li, L. (2005). The Effects of Trust and Shared Vision on Inward Knowledge Transfer in Subsidiaries' Intra- and InterOrganizational Relationships. International Business Review, 14(1), 77-95. DOI: 10.1016/j.ibusrev.2004.12.005 
Leydesdorff, L. (2012). The Triple Helix, Quadruple Helix, ..., and an N-tuple of Helices: Explanatory Models for Analyzing the Knowledge-based Economy? Journal of Knowledge Economy, 3, 25-35. DOI 10.1007/s13132-011-0049-4

O’Shea, G., Farny, S., \& Hakala, H. (2021). The buzz before business: a design science study of a sustainable entrepreneurial ecosystem. Small Bussiness Economics, 56, 1097-1120. https://doi.org/10.1007/s11187-019-00256-4

Petrevska Nechkoska, R., \& Mojsovska Salamovska, S. (2017). Context-appropriate implementation of blended learning in higher education in Western Balkans. In I. Vrdoljak Raguz (Ed.), DIEM: Dubrovnik International Economic Meeting (Vol. 3, pp. 506-518). Presented at the DIEM: Dubrovnik International Economic Meeting, Dubrovnik. Croatia: University of Dubrovnik.

Petrevska Nechkoska, R. (2019). Tactical management in complexity: managerial and informational aspects. Heidelberg: Springer. Retrieved from https://www.springer.com/gp/book/9783030228033

Petrevska Nechkoska, R., Angeloska Dichovska, M. (2020). MultiCreation - participatory learning approach for business academia collaboration. Teaching Methods for Economics and Business Sciences. Proceedings of the $3^{\text {rd }}$ International Scientific Conference. Maribor: University of Maribor Press, Slovenia. DOI https://doi.org/10.18690/978-961-286356-2.4

Phillips, W., Lee, H., Ghobadian, A., O’Regan, N., \& James, P. (2015). Social Innovation and Social Entrepreneurship: A Systematic Review. Group \& Organization Management, 40(3), 428-461. Sagepub.com, DOI: 10.1177/1059601114560063Sein,

M. K., Henfridsson, O., Purao, S., Rossi, M., \& Lindgren, R. (2011). Action design research. MIS Quarterly, 35(1), 37-56.

Tubbs, N. (2014). The new teacher: An introduction to teaching in comprehensive education. Abingdon, Oxfordshire: Taylor \& Francis. Wagner, E. (2011). Essay: In search of the secret handshakes of ID. The Journal of Applied Instructional Design, 1(1), 33-38.

\section{Vključitev študentov ekonomije in prometnega inženirstva $v$ vprašanja skupnosti $z$ uporabo pristopa $z$ večstranskim ustvarjanjem}

\section{Izvleček}

Učinkovite metode poučevanja naslednjih generacij pragmatičnih študentov in učiteljev se razvijajo v smeri veliko večje vključenosti na vseh straneh ter poskušajo povezati resnično življenje in akademsko okolje na številne inovativne načine. Naša teoretična podlaga temelji na principu trojne spirale, teoriji spirale z n-členi in inovacijskem trikotniku, vendar v multidisciplinarnem okolju ter na podlagi konkretnih primerov. Po uvedbi in potrditvi vsestranskega ustvarjalnega pristopa pri poučevanju/učenju za poslovno-akademsko sodelovanje, kjer so različne discipline, različni profili študentov, profesorjev in menedžerjev prevzeli različne vloge pri obravnavi ustreznih poslovnih vprašanj, smo želeli razširiti to uporabo tudi izven poslovnega sveta - na družbene probleme. Obdržali smo učenje na podlagi konkretnih primerov in sodelovalno učenje, vendar smo problem preusmerili v prometno varnost otrok v osnovnih šolah - vključujoč ekonomska, projektna, vodstvena, logistična, regulativna vprašanja in vprašanja glede upravljanja ter prometnega načrtovanja. Z vključitvijo dveh osnovnih šol, sodelovanjem z njihovimi ravnatelji, svetovalnimi skupinami in učitelji ter otroki in starši v dveh različnih mestih smo želeli zainteresiranim stranem zagotoviti popolne raziskave, načrtovanje in izobraževanje, tako da bi šole lahko predale dokumentacijo ustreznim občinskim organom, ki so pristojni za ukrepanje. Sodelujoči študenti so prihajali z dveh fakultet ekonomske fakultete in fakultete za prometno inženirstvo, vodili pa so jih trije univerzitetni profesorji na področju vodenja projektov ter osnovnih in naprednih tehnik upravljanja prometa. Komponente kombiniranega učenja so potekale, kot je predpisano v vsestranskem ustvarjalnem pristopu, med dvema semestroma dveh študijskih let s kombiniranimi protiukrepi ter rešitvami. Vsestranski ustvarjalni pristop ima izboljšane komponente in potek dela, njegova učinkovitost pa je potrjena v okolju več zainteresiranih strani pri neposrednih in posrednih udeležencih izobraževanja.

Ključne besede: učenje na podlagi konkretnih primerov, sodelovalno učenje, vsestranski ustvarjalni pristop, prometno inženirstvo, sodelovanje med skupnostjo in akademskim okoljem 